\title{
Making links in psychoanalytic interpretations: A conversation analytical perspective
}

\section{Perakyla, A}

2004

Perakyla , A 2004 , ' Making links in psychoanalytic interpretations: A conversation analytical perspective ' , Psychotherapy Research , vol. 14 , no. 3 , pp. 289-307 . https://doi.org/10.1093/ptr/kph026

http://hdl.handle.net/10138/33911

https://doi.org/10.1093/ptr/kph026

publishedVersion

Downloaded from Helda, University of Helsinki institutional repository.

This is an electronic reprint of the original article.

This reprint may differ from the original in pagination and typographic detail.

Please cite the original version. 


\title{
MAKING LINKS IN PSYCHOANALYTIC INTERPRETATIONS: A CONVERSATION ANALYTICAL PERSPECTIVE
}

\author{
Anssi Peräkylä \\ University of Helsinki
}

\begin{abstract}
Twenty-seven psychoanalytic sessions were tape-recorded and transcribed with the aim of describing key aspects of the psychoanalytic technique as they appear in these recordings. The method of the study, which included 2 experienced analysts and their 3 patients, was conversation analysis. This study focuses on interpretations that make links between different domains of the patient's experience (childhood, current everyday life, and the analyst-analysand relationship). The analyst is actively working to create a match between the different domains of experience by shaping the description of the patient's experience to display the "sameness" of the connected experiences. There are 2 loci for the analyst's work to create the match: One is the lexical choice within the interpretative statements, and the other is the sequence structure in the discussion that precedes the interpretations. The results are discussed in the light of Spence's concept of linguistic appeal of interpretations.
\end{abstract}

Typically in psychoanalytic literature, the psychoanalytic method is described in idealized terms without direct reference to actual recorded interactions. In this study, I report results from a research project in which actual psychoanalytic sessions were tape-recorded with the aim of describing some key aspects of the psychoanalytic technique as they appear in these recordings. The specific focus of the study is on interpretations. I show how the descriptions of the patient's experience involved in interpretations are jointly built up by the patient and the analyst and how the analyst contributes to the "linguistic appeal" (Spence, 1982, p. 140) of interpretations through word selection and sequence construction.

Conversation analysis (CA) was used as the research method. CA offers the means to describe actual practical working methods of professionals and clients in any setting in which language is the main medium of professional practice (Drew \& Heritage, 1992). In this study, I demonstrate and discuss the potential of CA as a method for psychotherapy research.

\footnotetext{
This research project was funded by the Academy of Finland and the International Psychoanalytic Association. I thank Sanna Vehviläinen for excellent collaboration and much appreciated help; Jukka Aaltonen, Jörg Bergmann, Brigitte Boothe, Mikael Leiman, Pirkko Niemelä, and Ulrich Streeck for many helpful comments on the data analysis; and all the members of Treatment Ideologies and Social Interaction research group for support and comments.

Correspondence concerning this article should be addressed to Anssi Peräkylä, Department of Sociology, PO Box 18, 00014 University of Helsinki, Finland. E-mail: anssi.perakyla@helsinki.fi.
} 
According to Rycroft (1995), psychoanalytical interpretations are "statements made by the analyst to the patient in which he attributes to a dream, a symptom, or a chain of free associations some meaning over and above (under and below) that given to it by the patient" (p.85; cf. Greenson, 1967, pp. 39-42; Sandler, Dare, \& Holder, 1992, pp. 147-162). In many interpretations, the analyst suggests that there are links between different domains of the patient's experience (his or her childhood, current everyday life experiences, and the analytic hour). In this study, CA is used to show how these linkages are gradually built up in the discussion that precedes the actual interpretation and how they are displayed in the actual interpretative statements.

\section{Data and Method}

The data come from 60 audio-recorded psychoanalytic sessions, collected in 1999-2000 for the research project Psychoanalysis as Social Interaction in Finland, involving 2 experienced analysts and 3 patients, with 20 consecutive sessions from each patient. The data analysis focuses on 27 randomly selected sessions from the corpus, of which 94 interpretative sequences were found. In this sample, one analystpatient dyad is represented by 10 sessions, another by 9 sessions, and the third by 8 sessions. This study focuses on the interpretations in which the analyst suggests that there are links between different temporal and social domains of the patient's experience (childhood, current everyday life, and the here and now of the analytic session). Of the collection of 94 interpretative sequences, 45 involve this kind of linkage. The remaining 49 interpretations are built differently: Rather than making explicit links between different domains of experience, they involve descriptions of the conflicts between different emotions (cf. Malan's triangle of conflict discussed later). Both analysts in our data use interpretations in which links are made, but in the "interpretative style" of one of them ${ }^{1}$ they are more dominant. Extracts presented here come from all three analyst-patient dyads.

$\mathrm{CA}$ is a qualitative approach for the study of the structure and the process of real-time social interaction (see Heritage, 1984; Drew \& Heritage, 1992; Hutchby \& Wooffitt, 1998; ten Have, 1999). It concentrates on "how" (rather than "what" or "why") questions, describing how interaction is organized so as to produce coordinated actions such as questions and answers, openings and closings of conversation, or turn taking. CA has been widely used in the study of different types of professionalclient interaction, such as counseling (e.g., Peräkylä, 1995) and medical consultations (e.g., Heritage \& Maynard, in press) but much less in psychotherapy (see, however, Buttny, 1996, 2001; Davis, 1986; Elliott, Slatick, \& Urman, 2001, pp. 94-98; Peyrot, 1982). This article originates in the first conversation analytical research project on psychoanalysis (for related studies involving qualitative analysis of tape-recorded psychotherapeutic interactions, see Ferrara, 1994; Flader, Grodzicki, \& Schröter, 1982; Labov \& Fanshel, 1977).

CA differs from quantitative methods of interaction research, such as Bales's (1950) interaction process analysis or Stiles's (1992) verbal response mode analysis, because it does not operate through coding and counting with a predefined set of categories; rather, it seeks to develop the key parameters of description qualitatively, in

${ }^{1}$ This analyst is the one with two patients (i.e., 40 sessions) in our dataset. 
an inductive way, so as to ensure the context sensitivity of the analytic apparatus in each study. CA differs from many other qualitative methods for research on language use, such as critical discourse analysis (Fairclough, 1995) or social constructionism (Gergen, 1994) because of its theoretical asceticism and its emphasis on the importance of empirical evidence (in actual data extracts) for any analytic claims. In current psychological research, the method that comes closest to CA is discursive psychology (Edwards, 1997; Edwards \& Potter, 1992), which has indeed adopted the analytical techniques and the basic concepts of CA.

The phenomena on which CA studies focus are different from those of most of the established methods of psychotherapy research. CA is a descriptive method focusing on the actual interactive behaviors; therefore, it does not in itself offer any means for assessing the outcome of psychotherapy. However, even in terms of process research, the questions with which CA deals are specific (cf. Elliott, 2002, p. 1; Wallerstein, 2002, pp. 30-31). The CA studies focus on the structures and patterns of the manifest social interaction. Hence, CA does not offer tools for describing the psychological change in the patient as, for example, Stiles's (Stiles et al., 1990) assimilation model does. The process that CA describes is strictly the interaction process, not the process of psychological change. Moreover, in describing interactions, CA focuses on specific recurrent sequences, such as those described here. Hence, it does not offer means for description of the global characteristics of whole sessions as, for example, Jones's (2002) psychotherapy process Q-sort does. Instead, the core contribution that CA can offer in research on psychotherapy as well as on any other form of institutional interaction is the meticulous description of practices through which the participants accomplish their tasks. This study demonstrates one aspect of such contribution.

When CA is used in the study of institutional interaction (e.g., professionalclient encounters, meetings, interviews), the central aim of research is to show how the participants accomplish their institutionally ascribed tasks. As Drew and Heritage (1992; Heritage, 1997) pointed out, CA studies typically focus on one or more of six overlapping layers of organization that can be involved, including turn-taking organization, overall structural organization (i.e., the ways in which encounters are organized as a continuum of distinct phases), sequence organization (i.e., the ways in which consecutive utterances are linked), turn design (i.e., syntactical and other linguistic properties of utterances), lexical choice, and interactional asymmetries (i.e., the systematic differences in the participants' modes of participation). Giving interpretations is a central task of psychoanalysts. This study presents an analysis of how lexical choice and sequence organization are involved in the accomplishment of this task.

The research process in CA can be described as a continuum of several steps (see Peräkylä, 2003b). It begins with tape-recording and transcribing the interactions to be studied. In the transcription, detailed notation developed by Gail Jefferson is used (see Appendix; in the extracts presented here, however, some signs indicating prosodic features have been omitted). An important step in the research process involves unmotivated exploration of data, which is often done in teams. In this research, much of this exploration occurred between the author and Dr. Sanna Vehviläinen. The goal of the unmotivated exploration is to identify recurrent actions and patterns of interaction that are characteristic for the data studied. One result of this stage in this research was the observation that the analysts' interpretations often involve linkages between different domains of patients' experience. 
As soon as recurrent actions or patterns of interaction have been identified through the unmotivated exploration of data, the next phase of research, which involves creation of collections of segments of interaction where these actions or patterns occur, can begin. In this research, all segments in which the analysts gave interpretations were collected from the data transcribed thus far. A large portion of these segments involved linkages between different domains of patients' experience. A crucial phase in the conversation analytical research involves the case-bycase analysis of the segments included in the collection, with the aim of showing the different trajectories that the action in question can take and the layers of organization that are involved in its production. In our research, the more detailed analysis of interpretative segments focused on the interactional moves and actions that make possible the linkages between different domains of experience. Lexical choice and sequence organization were centrally involved in this. The analysts' ways of choosing words and descriptions, and the ways in which utterances were connected to other utterances in sequences that lead to interpretations, appeared as central means for establishing linkages between different domains of the patient's experience.

Even though a full review of psychoanalytic literature on interpretations is beyond the scope of this study, a brief account of relevant psychodynamic theory is essential before the actual empirical findings are reported.

\section{Making Links Between Different Domains of Experience in Psychoanalytic Dialogue}

Malan (1979) provided an illuminating theoretical description of the links between different domains of experience. Even though Malan's book is about dynamic psychotherapy rather than analysis proper, his conceptualization has been adopted by psychoanalysts (see, e.g., Bateman \& Holmes, 1995, pp. 170-173), and it also fits well with our data. Malan indeed draws heavily on a central psychoanalytic theorist, Karl Menninger (1958), in depicting "two triangles" that are meant to give means for representing "almost every intervention that a therapist makes" (Malan, 1979, p. 80).

This study focuses on interpretations involving the triangle of person. Its angles represent the patient's relation to different personae in his experience. "Other" means the significant others in the patient's life outside the analytic hour, "transference" is the relation to the analyst, and "parent" refers to the important persons in the patient's childhood. The different angles also represent different temporal orders: "other" involving current or recent past, "transference" involving here and now, and "parent" involving usually distant past. The three sides of the triangle represent linkages among the key personae. In their interpretations, therapists make these linkages (i.e., they propose to the patient that the patient's experience having to do with one angle might be linked to personal experience related to another angle).

However, the patients are not always ready to see the linkages between the different angles of the triangle of person. The difficulty is represented by the other triangle, called the triangle of conflict, which depicts the dynamics among defense, anxiety, and hidden feeling. The current study proposes that the analyst works in manifold consistent ways to build up the plausibility of the linkages between the different angles of the triangle of person. Each angle involves a specific domain of experience, and the analyst works to create a match between them. There are two key aspects to this: The analyst (a) chooses words in his or her own interpretative 
utterances that allow for links to be made and (b) builds up sequences that allow for links. I suggest that creating a match between the connected domains of experience is an important but thus far neglected aspect of the technique and skill of giving interpretations. As a whole, the analysis of data presented here lends support to and further specifies Spence's (1982) theoretical arguments suggesting that linguistic appeal is a decisive feature of psychoanalytic interpretations and that interpretation is a creative and constructive (rather than reconstructive) act.

Before the presentation of the more detailed results of the data analysis, I illustrate the making of links with the help of a data extract. The patient in the following extract is the principal of a foster care institution for adolescents. Earlier during this session, he spoke about the conflict between the male and the female staff of the institution and about the criticism that the children have targeted at the staff. Immediately before the interpretation, there was talk about the patient's parents' divorce, which took place when he was a child.

1 T. .hhhhh So that one could think that when you are describing the

2 situation where.hhhhhhh er:: the women of your institution

3 are: angry at the men of the institution, (.hhhhhhh) that

4 (against the)(you thi-) (be) offended.

$5 \quad$ They may have a feeling that (1.6) that women are not

6 (always) valued enough.

$7 \quad(0.8)$

8 T. And then: (0.2) the children are discontent with you.

9 (1.6)

10 T. So: er:- it may be that you are then describing (0.8)

11 the situation of your family at the point when (0.8)

12 the divorce had not yet taken place.

13 (1.4)

14 T. But um:: when the- (0.5) unity of the family had disappeared.

15 (4.8)

16 T. So that you may be anxious because (1.6) the unity of your team, (0.4) you are afraid that it has disappeared. (2.0)

T. And because you would have to take si:des as you had to take sides also back [then at] home.

C. [mm:: ] (15.0)

C. nffff hhhhhh

25 C. .hhhhhhhhh hh Yeahhh it's hh true yes mhhhhhhh.

In his utterance, the analyst makes extensive references to narratives and descriptions of events that the patient has proffered in this session and to some extent also in earlier sessions. In the first part of the interpretation (Lines 1-14), he suggests that when the patient describes events at the institution of which he is the principal, he is at the same time describing the situation in his own childhood family before his parent's divorce. In the second part of the interpretation (Lines 16-20), he suggests that the patient may be worried about his team losing its unity, which would lead to a situation in which the patient would have to take sides, as he had to take sides when his childhood family was breaking up. Thus, in both parts of the 
interpretation, the analyst brings together both current and childhood experiences, making links between the past and present.

The interpretations, as they occur, may appear as simple and straightforward operations, involving the analyst's assertion where he connects the different themes that have arisen in the patient's prior discussion. However, the analyst has to work to make them possible, plausible, and persuasive. A key aspect of this interactional work is the shaping and reshaping of the descriptions of the patient's experience in ways that allow for connections to be made between different domains of experience. I examine this (re)shaping of descriptions in two different contexts: in the lexical choices within the interpretative utterances and in the sequence organization of talk that precedes the interpretations.

\section{Lexical Choice}

The interpretative utterances not only connect but also shape and reshape what is connected by the consequence of making the connections plausible. This occurs through the choice of words. ${ }^{2}$ In the interpretations, the analyst (re-)explicates either one or both experiences that are being connected. The explication of the experiences can be done using words that display the match between the two experiences. A central technique used in this could be called circulation of figures. With this technique, the same figures of speech are used in descriptions of both experiences connected in the interpretation. Let us reexamine the prior extract to illustrate this.

The analyst uses two figures of speech-"the unity has disappeared" and "have to take sides"-in descriptions of both the childhood experience (Lines 14 and 19-20) and the adult workplace experience (Lines 16-17 and 19) of the patient. When referring to the patient's childhood experience, the analyst states, "The... unity of the family had disappeared and you had to take sides also back then at home." When referring to the adult workplace experience, he states, "The unity of your team ... you are afraid that it has disappeared and... you would have to take sides." The connectedness of these experiences is embodied and displayed in this choice of words. Had the analyst used different words for describing different experiences, this kind of display of linkage would not have been possible. For example, had he said in Line 14 "when your parent's relation had collapsed" (instead of "when the... unity of the family had disappeared"), the connection to the description in Lines 16-17 would have been lost (unless that description would have been altered accordingly).

In the first extract, the circulation of figures occurred "within" the analyst's utterance: The figures used in the descriptions of the two domains of experience both originated in the analyst's own talk. In some other cases, the analyst circulates figures that originate in the patient's talk preceding the interpretation. An example is provided in the following extract. During this session, the participants have talked extensively about the patient's difficulties in her relation to her mother. Just before the extract, the analyst asks whether the patient has ever shouted at her. A story about the mother buying the wrong kind of clothes for the (then teenaged) patient ensues.

\footnotetext{
${ }^{2}$ In earlier psychotherapy research, lexical choices have been successfully studied in terms of the generation and the use of metaphors (see, e.g., Agnus, 1992; Rasmussen \& Agnus, 1996). My analysis does not focus so much on the metaphorical or other content of the selected words, but to the relations between word selections in different utterances.
} 
01 C. But I was so disappointed and angry then when she had bought me (0.6) trousers and winter boots

03 when I: and shoes when I had just thought

04 which kind of ones I want and would have wanted.

(10 lines omitted)

15 C. What I rem[member is that I really tried and

16 T. [Yes yes,

17 C. hhhh[h express that and show it concretely that I

18 T. [yeah,

19 C. want to choose mys[elf..hh And no no so mother just

20 T. $\quad[\mathrm{Mmmm}$.

21 C. completely got crushed. (0.4) And I felt that was

22 quite horrible then I thou[ght that I'll leave it.

23 T. [And then so then you

24 stopped shouting.

25 C. Yeah,.mthh plus then that that yeah the (),

26 T.

27 yourself.

28 C. What.

29 T. [Ge- so that you get crushed yourself you say that you

30

31

32

33

are depré $[$ ssed and.hhh and to you cru- b: you

C. $\quad$ Yeah right but $\mathrm{m}$ :

T. get crushed also in another waly ( ).

C.

[Yeah,

In Line 21, the patient describes her mother's reaction to her anger using the phrase "mother just completely got crushed"; she continues the narrative by telling how she felt about the mother's reaction and consequently abandoned her criticism (Lines 21-22). In overlapping talk, the analyst first suggests that, at that point the patient stopped shouting at her mother (Lines 23-4), implying that after this event the patient started to repress her anger. In Line 26-27, she then proposes that now the patient herself gets crushed. This proposal involves an interpretation that establishes a linkage between the patient's adolescent experience of the mother not being able to tolerate her anger and her current plight (manifested as depression and feelings of unworthiness, discussed elsewhere in this and the preceding sessions). The linkage between the adolescent and current experiences and the dynamics between repressed anger and depression are embodied in the circulation of the figure "get crushed."

Likewise, in the next extract, the analyst demonstrates the connectedness of two domains of experience by circulating figures. In this case, the interpretation establishes a parent-transference link. The patient is the same as in the first extract, but this is another session. Before the segment, the analyst has pointed out to the patient that he seems to have problems in associating freely. In Line 1, he asks the patient to nominate the things that he "can't say."

01 T. Or what is the thought that you can't say.

$02 \quad$ (15.0)

03 C. .mthhhhh hmmmmmmm (0.7) mhhhhh

$04 \quad$ (3.2)

05 C. .mthh (1.5) A memory comes to my (0.3) mind about

06 father trying to teach me to read or (.) count 
07 either or and,

$08 \quad$ (1.3)

09 C. hheh $\mathrm{H}(\mathrm{h}) \mathrm{e}$ well.hhh (0.4) erm: he was not a good

10 (.) teacher.

11 (0.6)

12 T. .hh erm.hhh (In other words it) is irritation.

13 (1.0)

14 T. It is exactly that this is an excellent

association..hhh This is exactly that situation.

(0.5)

17 T. I'm trying to teach you.hh[h I'm not a good

18 C. [hheh

19 T. teacher.

20 (0.6)

21 T. .mhh And you get irritated at me at this mome[nt.

22 C.

$[\mathrm{mhhh}$

As a delayed response to the analyst's question, in Lines 5-10 the patient tells him about a childhood memory of his father trying to teach him. In Line 12, the analyst first formulates what he takes to be the meaning of this association: The patient is prevented from talking by irritation (see Vehviläinen, 2001). Then, in Lines 15-21, the analyst gives an interpretation in which he links the patient's childhood experience of his father to the current situation at the analysis: In the here and now of the transferential relation, the patient is in a similar relation to the analyst as he was when his father tried to teach him. In the interpretation, the analyst circulates the phrases "trying to teach" and "not a good teacher," originating in the patient's description of his childhood memory (see Lines 6 and 9-10) and substituting himself for the father (in Lines 17-19). Again, the link between the childhood experience and the current experience is incorporated in the use of the same figures of speech in both descriptions.

In this section, I have shown how the analyst uses recognizably same words or descriptors to describe the domains of experience that he proposes are linked. Through these lexical choices, the analyst (re)shapes the descriptions of the patient's experiences in such ways as to allow for these experiences to be linked to other domains of experience, in terms of other-parent, other-transference, and transference-parent links. The circulation of figures makes the connectedness of the different domains of experience visible, concrete, and plausible. The analyst is not only neutrally presenting his or her objective observations to the patient but is working actively to make the linkages plausible and persuasive. In the following section, I turn to the analyst's practices before the actual interpretative utterances: practices through which the analyst "prepares the ground" for the interpretations.

\section{Sequence Organization in Talk That Leads to Interpretations}

As Vehviläinen (in press) has pointed out, the analyst often builds up a case for the interpretation in a long stretch of preceding talk, establishing some aspects of the patient's experience/narratives as puzzling and needing explanation. This is done through various interventions, including confrontations, reformulations of the patient's talk, and utterances in which the analyst continues the patient's utterances. In the following sections, I argue that one aspect of this preparation is to establish a 
shared understanding of some aspect of the patient's experience in such terms that allow for its linkage to another domain of experience. In the discussion that precedes the interpretations in which links are made, the analyst often builds up sequences that enable him or her to re-explicate the patient's experience in ways that create a potential match between its different domains, thus making the potential linkages plausible.

I examine two sequential patterns that make this kind of shaping of descriptions possible. One involves the analyst's evaluation in response to a narrative told by the patient, and the other involves the analyst's commentary on the patient's response to the analyst's confrontation.

Story evaluation. The sequence consisting of a story and the subsequent evaluation is generic: It can be found in almost all interactions in which stories are told (see, e.g., Labov, 1972; Sacks, 1974). This generic sequence can be used by the analyst to establish such shared understandings of the patient's experience that allow for links to other spheres of experience to be made in the interpretation that succeeds the evaluation. Story evaluations occur after the patient's narratives, and they highlight some aspect of it. The highlighted aspect may be one that allows for a connection to another realm of experience to be made. The following extract shows the final part of a long narrative about the patient's visit to the hospital where her partner (Jussi) is treated for terminal illness.

01 C. I do think that he recognizes familiar faces and sounds (2.5) human voices, familiar human voices.

(8.2)

C. Mt. so (.) Jussi says hardly anything.hhh erm that thathat I would understand, but then I said.hh while this this Antti had been there.hhh so I said that "Antti brought you flowers from Anna Virransalmi." $(0.3)$

C. So then he said "Yes, I thought that (0.9) that let's do it that way it is indeed the best."

(0.7)

C. So so (that) (1.4) then again remains sort of quite incomprehensible. (0.7) So that after all h- h- he didn't understand what I said.

T. ((clears throat)) (5.0)

C. $\mathrm{mt}(0.4)$ Well. $(0.2)$

T. .hfff I think that it was quite (0.5) it's w- (0.2) it was harder than you were able to say.

C. Mthh. Yes it is frust[rating that]

T. [as you noti]ced (0.2) in the beginning (0.2) you were (.) very angry at me: (2.7)

T. (And) I think that it is connected to the fact that that the (1.5) weakening and death of Jussi and the (0.9) struggle of yours to understand Jussi and to support him (1.2) that is much harder (1.6) than what you:: (0.2) actually have 29 the courage even to think about. so that makes you angry. $30 \quad$ (0.6) 
31 T. (That) the anger gets directed at me.

$32 \quad(0.2)$

33 C. Yea:h. (0.2) Who knows.

$34 \quad(0.5)$

35 C. In any case I do ermh understand (1.0) and

36 admit (1.6) $\mathrm{mt}$ that it is hard no doubt about that.

The climax of the patient's narrative involves a citation of Jussi's incomprehensible talk in Lines 9-10, followed by the patient's assessment of Jussi's state of consciousness in Lines 12-14. The analyst proffers a story evaluation in Lines 19-20, proposing that the patient may have felt her partner's lack of consciousness was more difficult than she was able to verbalize.

The story evaluation highlights the meaning of the narrative in terms of the patient's subjective experience. The patient's narrative focused on events at the hospital and on her partner's state of consciousness. The analyst's evaluation, in contrast, focused on the patient's subjective experience of these events. The evaluation also proposes that the patient has not been able to express the full subjective meaning of the events for her (Lines 19-20: “... it was harder than you were able to say" ).

The patient gives a qualified confirmation of the evaluation in Line 21. In overlap with that, the analyst then enters into an interpretation in which he makes an other-transference link. In the first part of the interpretation (Lines 22-23), the analyst reminds the patient about her anger at him at the beginning of the session. In the second part (beginning from Line 25), he explains the patient's anger by referring to the hardship experienced by the patient because of her partner's illness. The description of the patient's predicament is designed to hinge on the preceding story evaluation (e.g., by recycling the expression "it is harder"; see Lines 19-20 and 28). However, the analyst elaborates and intensifies the characterization of the patient's position incorporated in the story evaluation (e.g., by shifting to present tense, explicating different aspects of both the partner's illness and the patient's relation to him, adding an intensifier "much" in Line 28, and substituting "have the courage even to think" [Line 29] for "were able to say" [Line 20]).

In sum, the patient's story focused on events at the hospital and on the partner's state of consciousness. It would not in itself afford the linkage to be made to the patient's anger. The analyst's evaluation in Lines 19-20, in contrast, focuses on the patient's own experience of these events. It proposes the kind of version of the patient's experience that would allow for a plausible linkage to the patient's anger. In the analyst's verbal description of the patient's predicament in Lines 26-29, he further expands, specifies, and intensifies the description of the patient's inner predicament. So, through the story evaluation and its elaboration in the interpretative utterance, the analyst achieves a plausible match between the patient's transferential anger toward the analyst and the events at the hospital initially described by the patient in her narrative.

The sequence consisting of the patient's story and the analyst's subsequent evaluation provides an opportunity for the analyst to reshape the description of the patient's experience in ways that allow for it to be linked to other domains of experience, in an interpretation that comes after the evaluation. Story evaluation occurs in the "second position" (Schegloff, 1995): It is the analyst's response to an action initiated by the patient. In a similar vein, the analyst can reshape the description 
of the patient's experience through "third-position" acts (i.e., by acts that deal with, and occur after, the patient's response to an initiatory action performed by the analyst). An example of a third-position act is presented next.

Commentary on the patient's response. The fifth extract (presented next) represents a case in which the analyst uses third position to highlight such aspects of the patient's experience that allow linkages to other domains of experience. In this case, the analyst's first-position initiatory act involves a remark regarding the patient's way of talking about his parent's divorce. This remark, which in psychoanalytic parlance would be called confrontation (see Sandler, Dare, \& Holder, 1992, p. 153; cf. Vehviläinen, 2003), invites an account from the patient as a response. The analyst's third-position act involves a commentary on the patient's account. In his commentary, the analyst re-explicates the patient's childhood experience in terms that allow it to be linked to his current experience. The link is made in the subsequent interpretation.

In Lines 1-3, the analyst does "confrontation" by pointing out that the patient has described his parents' the divorce as if it were an "easy" event. The patient responds by first describing the hardship in the family before the divorce (Lines 21-27) and then proposing that, after such hardship, the actual divorce came as a relief (Lines 28-45). At the end of his utterance, the patient literally admits what was suggested in the confrontation (Lines 46-47). The extract is an expansion of the first one presented.

01 T. When you have described their: (0.5) divorce you have described it (0.8) as if it were somehow as an easy

(18 lines omitted)

21 T. .hhhhhhhhhh it isn't (0.2) perhaps its erm hhmmmm (1.0) mt.hhhhh Perhaps it uhm erm erm ehhhh. so as (.) as the situation, (.) as it was (0.4) extremely difficult time, (3.0) the time before the divorce. (2.0)

C. There were the rows and father was drinking and, (1.6) and the permanent uncertainty and (1.6) what ever, mt.hhhhhh and then when it like ermhhhhh (0.8) .hhhh when the divorce took place as the:: decision was like ma:de in that (0.4) family then (.hhhhhhhhh) then it has been some kind of relief it indeed has been (so) the situation has been like so:lved in some way. (0.8)

T. Yea:h.
(1.0)

C. And (that is) like- $(0.5)$ perhaps that is the feeling of relief which has there like.hhhhh in a way characterized the whole d- divorce in such a way that (.hhhhhhh) in my mind that the- that I have like, (0.8) it has like been covered then when the: (.) the erm:: (1.2) it was you know a loss of one's father. So that has as if that:: feeling has like been covered by that, $\overline{(0.4)}$ feeling of $(0 . \overline{2})$ relief which has somehow characterized the whole (1.4) thing so: 
46 so I (do) give the picture

47 that it has (been) easy or, h (1.8) I don't know. Hh

48 T. mt.hhhhh (0.2) It may very well be like that. An:dm

49 .hhhhhh an:d before the loss of father there was also

50 the situation, mt.hhhhhh when you had had already

$51 \quad$ lost $(0.5)$ the relation of your parents.

$52 \quad(0.2)$

53 C. $(\mathrm{mm}-\mathrm{hm})$,

$54 \quad(0.8)$

55 T. The relation of the parents is nonetheless one, (1.4) it is

C. Yeah: (13.0)

T. hhhhh So that one could think that when you are describing the situation where.hhhhhhh er:: the women of your institution

61 are: angry at the men of the institution, (.hhhhhhh) that

62 (against the)(you thi-) (be) offended.

63 They may have a feeling that (1.6) that women are not

64 (always) valued enough.

$65 \quad(0.8)$

66 T. And then:, (0.2) the children are discontent with you.

$67 \quad(1.6)$

68 T. So: er:- it may be that you are then describing (0.8)

69 the situation of your family at the point when (0.8)

70 the divorce had not yet taken place.

$71 \quad(1.4)$

72 T. But um:: when the- (0.5) unity of the family had disappeared.

73 (4.8)

74 T. So that you may be anxious because (1.6) the unity of your

75 team, (0.4) you are afraid that it has disappeared.

$76 \quad(2.0)$

77 T. And because you would have to take si:des as you had to

78 take sides also back [then at] home.

79 C. $[\mathrm{mm}: .$.

In his commentary after the patient's response to his confrontation, the analyst first accepts the patient's response in Line 48. A more elaborated commentary ensues in Lines 49-51 and 55-56, in which the analyst describes, using general psychological terms, the patient's circumstances before the divorce. Through this thirdposition commentary, the analyst highlights specific aspects of the patient's experience described by him in his preceding turn. The analyst shifts away from the feeling of relief associated with the divorce, described by the patient in the latter half of his utterance, as well as from the actual experience of the divorce, described by the patient briefly by the phrase "loss of one's father" in Line 42. Instead, he highlights and elaborates the patient's painful experience before the divorce. This experience was described by the patient at the early part of his prior utterance (Lines 23-27). The patient's initial account of the time before the divorce focused on the presence of something negative (fights, drinking, and uncertainty), whereas the analyst's account foregrounds the absence of something positive (the patient had lost the relation of his parents). 
After the patient has acknowledged and minimally accepted the analyst's account of his circumstances before the divorce (Lines 53 and 57), the analyst enters into an interpretation in Line 59. In the interpretation, he makes an other-parent link between the patient's current problematic experiences at the workplace and his childhood experiences during the time before his parent's divorce. Through the turninitial "SO" in Line 59, the interpretation is presented by the analyst as a summary or inference based on the prior talk. The analyst's description of the patient's childhood experiences incorporated in the interpretation (see especially Lines 69-72) hinges on his prior third-turn commentary. In both, the analyst focuses on the time before the divorce rather than the experience of the actual divorce. Moreover, both in the commentary and in the interpretation, the analyst adopts the perspective of absence rather than presence. In the interpretation, the perspective of absence is incorporated in the phrase "the unity of the family had disappeared" in Line 72.

In sum, the third-position commentary by the analyst in Lines 48-56 highlighted, refocused, and elaborated the patient's prior description of his childhood experience in such ways that made possible the linkage to his current workplace experience in such terms as it was made in the actual interpretation.

\section{Conclusion}

I have used the CA method to understand interactional aspects of psychoanalytic interpretations in which links between different domains of the patient's experience are made. As its result, the research yielded descriptions of lexical choices within the interpretative utterances and sequence organization preceding the interpretations. The key lexical choices involve circulation of figures through which the descriptions of the patient's experience are reshaped in ways that afford them to be linked. The sequence organization in the discussion that precedes the interpretations provides the analyst for opportunities to re-explicate patients' experience in ways that make the linkages possible in the subsequent interpretations.

Shaping and reshaping descriptions of experience, to afford linkages between them, is one central aspect of the work of a psychoanalyst (and probably of other therapists as well). With the help of conversation analysis, I have shown some interactional practices through which this task is accomplished. I hope to have offered a specification to our understanding of psychoanalytic technique concerning interpretations.

As Jones (1997) and Streeck (2001), among others, have pointed out, there are two opposed ways of understanding the place and significance of interaction in psychoanalysis. One view emphasizes the neutrality and objectivity of the analyst as an "observer of his patient's unconscious mental reality" (Streeck, 2001, p. 74). Even though interactive phenomena sometimes intervene in the therapeutic process and may as such be important sources of information for the analyst, the analyst should "try to withdraw from the interactive event... and to recover his position as neutral, objective observer" (Streeck, 2001, p. 74). The other view considers the analytic event as a thoroughly interpersonal one. It is a "realm created by both participants... a world of experience jointly brought forth by the analysand and the analyst together" (Streeck, 2001, p. 74) through their interactions. Thus, one view emphasizes the analyst's neutrality and considers interactive phenomena as contingent, whereas the other considers psychoanalysis as a thoroughly interactive process. The place and significance of interpretation are seen differently in these 
two views. The proponents of the former view traditionally emphasize the importance of interpretation, and the ensuing insight, as a mutative factor in the patient, whereas the proponents of the latter consider the very interactive processes and the associated relationship components (e.g., empathy, holding, and containment of feelings) as crucial for change (see, e.g., Bateman \& Holmes, 1995, pp. 166-169; Jones, 1997, pp. 1135-1136).

The observations presented here can be contextualized in this debate. Close examination of the verbal exchanges between the analysts and the patients demonstrates the interactive character of the psychoanalytic event. The descriptions of the experience of the patient, manifest in the segments of psychoanalytic dialogue that we have been investigating, were joint constructions of the patient and the analyst. The analysts were not acting like "mirrors" for their patient's unconscious mental realities but were active cocontributors to the reality discussed in these sessions. In terms of the division between the two opposite strands of psychoanalytic thinking outlined previously, interpretations should be moments in which the "objectivist" aspects of the analyst's role are most manifest. The research reported here suggests, however, that the interpretations are probably no less interactive products than the rest of the analysis.

Among the psychoanalytic scholars, Spence (1982) has consistently advocated this kind of view concerning interpretations. For him, linguistic appeal (and not historical truth value) is a decisive feature of interpretations (Spence, 1982, p. 140). Interpretations propose "pattern matches" between current and past events, and in establishing the matches "much depends on...how the interpretation linking two events is worded by the analyst" (Spence, 1982, p. 145). Numerous linguistic descriptions are always available for depicting a particular object or event, and when giving interpretations, the analysts, according to Spence, "choose a label or a phrase in order to create correspondence" (p. 150). Therefore, for Spence, interpretation is "a creative act" (p. 164) or an act of construction rather than reconstruction (p. 35). Using naturally occurring tape-recorded data, I have shown two central dimensions - circulation of figures of speech and sequence organization that creates opportunities for the analyst to rephrase the patient's descriptions of experience-of the creative aspect of interpretations.

Emphasizing the linguistic and creative aspects of interpretation does not mean to discredit them. Ikonen (2002) points out that all interventions and interactions in psychoanalysis should be assessed regarding the basic aim of psychoanalysis, which is to help the patient examine the unconscious aspects his or her mind. Spence (1982, pp. 166-172, 263-278) argues that interpretations with linguistic appeal may be therapeutically effective because, rather than in spite of the fact that, their persuasiveness is linguistically based. CA cannot judge the therapeutic effects of interpretations, let alone assess their historical truth value. However, the examination of the patients' interactional responses to interpretations can be informative for the assessment of their adequacy; an analysis of these responses is reported elsewhere (Peräkylä, 2003a).

The linguistic practices discussed here may not be exclusively psychoanalytical. Descriptions that afford linkages are those that exhibit some sort of sameness, and it is the sameness that the analyst's actions enhance. "Sameness" of different descriptions is something that agents in some other institutional contexts work to establish. For example, Lehtinen (2002) has shown how, in the bible study of Seventh-Day Adventists, the teacher uses the same words in referring to biblical texts and the everyday life of the participants, thereby establishing connections between 
the world of the bible narratives and the participants' everyday life. In a similar vein, Lindfors (2004) has shown how in homeopathic consultations the therapist and the patient work toward establishing a match between the descriptions of symptoms and personality traits as they appear in homeopathic books and the actual experiences described by the patient. In both bible study and homeopathy, what is sought is a fit between a textual description and an oral description of experience, whereas in psychoanalysis the fit that is sought is between different domains of the patient's experience, all orally described by the participants. In spite of this difference, one might hypothesize that the professional's action in all these three contexts represents a generic moment of institutional talk: the management of descriptions of individual experiences to make them fit into an underlying pattern. In bible study and homeopathic consultations, key components of this underlying pattern are textually given, whereas in psychoanalysis, more of it is locally constructed.

On the basis of the analysis presented here, it is possible to assess the potential of CA in psychotherapy research (cf. Elliott et al., 2001, pp. 94-98). The core contribution that CA can offer in research on psychotherapy as well as on any other form of institutional interaction is the meticulous description of practices through which the participants accomplish their tasks. This study focused on the psychoanalysts' task of giving interpretations, showing some practices of building up their "linguistic appeal." CA made it possible to describe how linkages are made in psychoanalytic interpretations. This is indeed a theme that has not been addressed to this detail in psychoanalytic texts or in earlier psychotherapy research.

Is a detailed description of interactional practices involved in psychotherapy useful and worthwhile in itself? Traditionally, psychotherapy and psychoanalysis have been learned, practiced, and even assessed without descriptions of this level of detail being available. Results like those reported here suggest, however, that there is a level of minutiae organization involved in practicing psychotherapy of which the practitioners, supervisors, and many researchers may not have been aware. If the psychotherapeutic practice involves this kind of interactional black boxes, opening them with the help of CA may offer new kind of self-understanding for the profession.

In future studies, the capacity of CA to describe in detail the patterns of interaction can also be used to clarify the actual differences between different psychoanalytical and therapeutic approaches. In terms of core concepts and theories, the different schools of psychoanalysis (such as classical, object relations, kleinian, or self-psychology) are quite far one from another. However, little is known about the differences between these schools in terms of the actual analyst-analysand dialogue. If there are systematic differences, as well as basic similarities, CA should indeed be able to describe them, and that should be informative also for those engaged in the theoretical debates.

Finally, in future research designs, CA could also be linked with outcome studies. As a strictly descriptive approach, CA on its own does not offer tools for outcome assessment. However, in fields other than psychotherapy, the specific contribution that CA can make has been integrated in outcome-oriented research (Boyd, 1998; Heritage, Boyd, \& Kleinman, 2001). This should also be possible in psychotherapy research. For example, in experimental outcome studies, in which comparisons are made between the effects of different therapeutic approaches (see Fonagy, 2002, especially pp. 156-178; Leuzinger-Bohleber \& Target, 2002), CA could be used as a subsidiary method through which the consistency within interactions belonging to 
the same approach, and differences between different approaches, could be controlled. Second, in research designs that involve contrasting successful and less successful therapies, or successful and less successful sessions, which, however, apply the same therapeutic approach (see, e.g., Jones, 2002), CA could be used to explore the interactional underpinnings of the actual differences between the successful and less successful therapeutic interventions. In studies of other institutional settings, CA researchers have identified different trajectories in the accomplishment of the core institutional tasks, such as problem presentation and diagnosis in general practice (see Heritage \& Maynard, in press). Similarly, different trajectories in key activities in psychotherapy could be detected and their possible involvement in the success or failure of therapies explored.

\section{APPENDIX: Transcription Symbols ${ }^{a}$}

\begin{tabular}{ll}
\hline Symbol & Meaning \\
\hline $\mathbf{C}$ & The patient (speaker designation) \\
$\mathbf{T}$ & The analyst (speaker designation) \\
{[} & Starting point of overlapping speech \\
$(2.4)$ & Endpoint of overlapping speech \\
$()$. & Silence measured in seconds \\
word & Pause of less than $0.2 \mathrm{~s}$ \\
wo:rd & Emphasis \\
wo(h)rd & Prolongation of sound \\
wo- & Laugh particle inserted within a word \\
$($ word $)$ & Cut off in the middle of a word \\
$($ ) & Section of talk that is difficult to hear but is likely as transcribed \\
. hhh & Inaudible word \\
hhh & Inhalation \\
$;$ & Exhalation \\
? & Falling intonation at the end of an utterance \\
$(($ word $))$ & Raising intonation at the end of an utterance \\
\hline
\end{tabular}

${ }^{\mathrm{a}}$ Simplified from Drew \& Heritage (1992).

\section{References}

Agnus, L. (1992). Metaphor and the communication interaction. In S. Toukmanian \& D. L. Rennie (Eds.), Psychotherapy process research. Paradigmatic and narrative approaches (pp. 187-210). Newbury Park, CA: Sage.

Bales, R. F. (1950). Interaction process analysis: A method for the study of small groups. Reading, MA: Addison-Wesley.

Bateman, A., \& Holmes, J. (1995). Introduction to psychoanalysis. Contemporary theory and practice. London: Routledge.

Boyd, E. (1998). Bureaucratic authority in the "company of equals": The interactional management of medical peer review. American Sociological Review, 63, 200-224.
Buttny, R. (1996). Clients' and therapist's joint construction of the clients' problems. Research on Language and Social Interaction, 29, 125-153.

Buttny, R. (2001). Therapeutic humor in retelling the clients' tellings. Text, 21, 303-326.

Davis, K. (1986). The process of problem (re)formulation in psychotherapy. Sociology of Health and Illness, 8, 44-74.

Drew, P., \& Heritage, J. (1992). Analyzing talk at work: An introduction. In P. Drew \& J. Heritage (Eds.), Talk at work (pp. 3-65). Cambridge, England: Cambridge University Press.

Edwards, D. (1997). Discourse and cognition. London: Sage. 
Edwards, D., \& Potter, J. (1992). Discursive psychology. London: Sage.

Elliott, R. (2002). Hermeneutic single case design. Psychotherapy Research, 12, 1-21.

Elliott, R., Slatick, E., \& Urman, M. (2001). Qualitative change process research on psychotherapy: Alternative strategies. In J. Frommer \& D. L. Rennie (Eds.), Qualitative psychotherapy research. Methods and methodology (pp. 69-111). Lengerich, Germany: Pabst Science.

Fairclough, N. (1995). Critical discourse analysis. London: Longman.

Ferrara, K. W. (1994). Therapeutic ways with words. Oxford: Oxford University Press.

Flader, D., Grodzicki, W.-D., \& Schröter, K. (Eds.). (1982). Psychoanalyse als Gespräch. Interaktionsanalytische Untersuchungen uber Therapie und Supervision [Psychoanalysis as conversation. Interactional studies on therapy and supervision]. Frankfurt: Suhrkamp.

Fonagy, P. (Ed.). (2002). An open door review of outcome studies in psychoanalysis. London: International Psychoanalytic Association.

Gergen, K. (1994). Reality and relationships. Soundings in social construction. Cambridge, MA: Harvard University Press.

Greenson, R. R. (1967). The technique and practice of psychoanalysis. Madison, CT: International Universities Press.

Heritage, J. (1984). Garfinkel and ethnomethodology. Cambridge: Polity Press.

Heritage, J. (1997). Conversation analysis and institutional talk: Analysing data. In D. Silverman (Ed.), Qualitative research: Theory, method and practice (pp. 153-174). London: Sage.

Heritage, J., Boyd, E., \& Kleinman, L. (2001). Subverting criteria: The role of precedent in decisions to finance surgery. Sociology of Health and Illness, 23, 701-728.

Heritage, J., \& Maynard, D. (Eds.). (in press). Practicing medicine: Talk and action in primary care encounters. Cambridge: Cambridge University Press.

Hutchby, I., \& Wooffitt, R. (1998). Conversation analysis: Principles, practices and applications. Cambridge: Polity Press.

Ikonen, P. (2002, August). Några tankar om bur man närmar sig det omedvetna [Some thoughts about approaching the unconscious]. Paper presented at the Nordic Psychoanalytical Conference, Oulu.

Jones, E. E. (1997). Models of therapeutic action. International Journal of Psycho-Analysis, 78, 1135-1150.

Jones, E. E. (2002). Interaction and change in psychoanalytic long-term therapy. In M. Leuzinger-Bohleber \& M. Target (Eds.), Outcomes of psychoanalytic treatment. Perspectives for therapists and researchers (pp. 280293). London: Whurr.
Labov, W. (1972). Language in the inner city: Studies in the Black English vernacular. Philadelphia: University of Pennsylvania Press.

Labov, W., \& Fanshel, D. (1977). Therapeutic discourse. Psychotherapy as conversation. Orlando: Academic Press.

Lehtinen, E. (2002). Raamatun puhuttelussa. Teksti, kokemus ja vuorovaikutus adventistisessa raamatuntutkiskelussa [Text, experience, and interaction in adventist bible study]. Acta Universitatis Tamperensis, 891. Tampere, Finland: Tampere University Press.

Leuzinger-Bohieber, M., \& Target, M. (Eds.). (2002). Outcomes of psychoanalytic treatment. London: Whurr.

Lindfors, P. (2004). Social interaction in homeopathic consultations. Unpublished doctoral dissertation, University of Tampere.

Malan, D. H. (1979). Individual psychotherapy and the science of psychodynamics. London: Butterworths.

Menninger, K. (1958). Theory of psychoanalytic technique. New York: Basic Books.

Peräkylä, A. (1995). AIDS counselling. Institutional interaction and clinical practice. Cambridge: Cambridge University Press.

Peräkylä, A. (2003a). After interpretation. Implicit resistance and co-construction in talk that follows psychoanalytic interpretations. Unpublished manuscript, University of Helsinki.

Peräkylä, A. (2003b). Conversation analysis. In C. Seale, J. Gubrium, G. Gobo, \& D. Silverman (Eds.), Qualitative research practice (pp. 165179). London: Sage.

Peyrot, M. (1982). Circumspection in psychotherapy. Semiotica, 65, 249-268.

Rasmussen, B., \& Agnus, L. (1996). Metaphor in psychodynamic psychotherapy with borderline and non-borderline clients: A qualitative analysis. Psychotherapy, 33, 521-530.

Rycroft, C. (1995). A critical dictionary of psychoanalysis. London: Penguin.

Sacks, H. (1974). An analysis of the course of a joke's telling in conversation. In R. Bauman \& J. Sherzer (Eds.), Explorations in the ethnography of speaking (pp. 337-353). Cambridge: Cambridge University Press.

Sandler, J., Hare, C., \& Holder, A. (1992). The patient and the analyst. The basis of the psychoanalytic process. London: Karnac Books.

Schegloff, E. A. (1995). Sequence organization. Los Angeles: University of California, Los Angeles, Department of Sociology.

Spence, D. P. (1982). Narrative truth and historical truth. Meaning and interpretation in psychoanalysis. New York: Norton.

Stiles, W. B. (1992). Describing talk. London: Sage.

Stiles, W. B., Elliott, R., Llewelyn, S. P., Firth-Cozens, J. A., Margison, F. R., Shapiro, D. A., \& Hardy, G. 
(1990). Assimilation of problematic experiences by clients in psychotherapy. Psychotherapy, 27, 411-420.

Streeck, U. (2001). "Ja, genau, genau.” Bestätigungen als Versuche des Patienten, die Kompetenz des Psychotherapeuten als eigene zu deklarieren. Eine gesprächsanalytische Untersuchung ["Yes, exactly." Confirmations as the patient's attempts to claim as his own the competence of the therapist]. Psychotherapie und Sozialwissenschaft, 2, 74-94.

Ten Have, P. (1999). Doing conversation analysis: A practical guide. London: Sage.
Vehviläinen, S. (2001). The analyst's requests for the patient to associate freely. Unpublished manuscript, University of Helsinki.

Vehviläinen, S. (2003). Preparing and delivering interpretations in psychoanalytic interaction. Text, 23, 573-606.

Wallerstein, R. S. (2002). The generations of psychotherapy research: An overview. In M. Leuzinger-Bohleber \& M. Target (Eds.), Outcomes of psychoanalytic treatment. Perspectives for therapists and researchers (pp. 30-52). London: Whurr.

\section{Zusammenfassung}

27 psychoanalytische Sitzungen wurden auf Band aufgenommen und transkribiert mit dem Ziel, Schlüsselaspekte der psychoanalytischen Technik, wie sie in diesen Aufzeichnungen erscheinen, zu beschreiben. Die Methode der Studie, die 2 erfahrene Psychoanalytiker und ihre 3 Patienten umfasste, beruht auf der Konversationsanalyse. Die Studie konzentriert sich auf Interpretationen, die eine Verbindung herstellen zwischen verschiedenen Erfahrungsbereichen der Patienten (Kindheit, gegenwärtiges tägliches Leben, Beziehung zwischen Analytiker und Analysand). Der Analytiker bemüht sich, eine Übereinstimmung zwischen den verschiedenen Erfahrungsbereichen herzustellen, indem die Gleichheit verbundener Erfahrungen in ihrer Beschreibung durch die Patienten herausgestellt wird. Es gibt zwei Ansätze in der Arbeit des Analytikers, diese Gleichheit zu konstruieren: einer ist die Wahl der lexikalischen Ausdrucksweisen in den interpretativen Aussagen und der andere ist die Struktur der Abfolge in der Diskussion, die der Interpretation vorausgeht. Die Ergebnisse werden im Licht des Konzeptes der linguistischen Wirkung von Interpretationen wie sie von Spence beschrieben wurde, diskutiert.

\section{Résumé}

27 séances psychanalytiques ont été enregistrées et transcrites dans le but de décrire des aspects clés de la technique psychanalytique apparaissant dans ces enregistrements. La méthode de cette étude qui incluait 2 analystes expérimentés et 3 de leurs patients était l'analyse de la conversation. Cette étude focalise sur des interprétations faisant des liens entre des domaines différents de leur expérience (enfance, vie quotidienne actuelle, relation analyste-analysand). L'analyste cherche activement à créer une rencontre entre les différents domaines d'expérience en influençant la description de l'expérience du patient pour faire sortir la congruence des expériences connectées. Il y a deux leviers pour ce travail de l'analyste de créer la rencontre : l'un est le choix lexical dans les énoncés interprétatifs, l'autre est la structure des séquences dans la discussion qui précède les interprétations. Les résultats sont discutés sur la base du concept de Spence de l'attractivité linguistique des interprétations.

\section{Resumen}

Se magnetograbaron y transcribieron veintisiete sesiones psicoanalíticas con el objeto de describir aspectos clave de la técnica psicoanalítica según aparecían en estos registros. El método de estudio, que incluyó dos analistas experimentados y sus tres pacientes, fue el análisis de la conversación. Este estudio focaliza interpretaciones que vinculan diferentes dominios de la experiencia del paciente (niñez, vida cotidiana actual y relación analista-analizando). El analista busca activamente compararlos diferentes dominios de la experiencia presentado la descripción de la experiencia del paciente de modo que se vea la semejanza de las experiencias conectadas. Existen dos lugares para que el analista cree esa semejanza. Uno es la elección léxica en las expresiones interpretativas; la otra es la estructura secuencial en la discusión que precede a las interpretaciones. Los resultados se discuten a la luz del concepto de Spence del apelativo lingüístico (linguistic appeal) de las interpretaciones.

\section{Resumo}

Vinte sessões de psicanálise foram gravadas e transcritas com o objectivo de descrever aspectos chave da técnica psicanalítica tal como aparecem nestas gravações. O método de estudo, o qual inclui 2 analistas experientes e os seus 3 pacientes, foi a análise conversacional. Este estudo foca-se nas interpretações 
que formam associações entre diferentes domínios da experiência do paciente (infância, o dia-a-dia, e a relação analista-analisado). O analista trabalha activamente para criar uma correspondência entre os diferentes domínios da experiência moldando a descrição da experiência do paciente de modo a expor a "uniformidade" das experiências relacionadas. Há 2 loci para o trabalho do analista em criar a correspondência: uma é a escolha lexical contida nas afirmações interpretativas, e a outra é a sequência estrutural do debate que precede as interpretações. São discutidos os resultados à luz do conceito de Spence de apelo linguístico de interpretações.

\section{Sommario}

Sono state audio-registrate e trascritte ventisette sedute con lo scopo di descrivere gli aspetti chiave della tecnica psicoanalitica così come appaiono in quelle registrazioni.

Il metodo dello studio che includeva due terapisti esperti e tre pazienti era un'analisi della conversazione. Questo studio si focalizza sulle interpretazioni che realizzano connessioni tra differenti domini dell'esperienza del paziente (infanzia, vita quotidiana, relazione terapeuta-paziente). L'analista lavora attivamente per creare un collegamento tra i differenti domini dell'esperienza modellando la descrizione dell'esperienza del paziente per mostrare la somiglianza tra le esperienze connesse. Ci sono 2 aree sulle quali lavora l'analista per creare il collegamento: una è la scelta lessicale all'interno delle interpretazioni e l'altra è la struttura della sequenza nella discussione che precede le interpretazioni. I risultati sono discussi alla luce del concetto di Spence di "linguistic appeal of interpretations."

\section{摘要}

27 次的心理分析治療錄影並腾宾為逐字稿, 用來描述錄影带中出現的心理分析技 術的重要面向。研究對象是兩位有經驗的分析師, 以及他們的三位病患, 對話分 析是資料分析的方法。研究聚焦在連結病患不同範疇的經驗（幼年期、目前日常 生活、分析師與被分析者間的關係) 作出的解釋。分析師積極地在病患描述的不 同範瞦經驗間, 找到相似可連結的經驗䂰造出配對。研究發現分析師䂰造出的配 對有雨處: 一是在解釋性的陳述中作語句的選擇, 另一是在作出解釋前討論的順 序結構。此結果依據 Spence 語言解釋的概念作出討論。

Received June 11, 2002

Revision received June 6, 2003

Accepted July 15, 2003 